\title{
Relationship of Emotional Intelligence and Academic Performance among Medical Students: Systematic Review
}

\author{
Ivan Rolland Karkada ${ }^{1,2}$, Urban John Arnold D'souza ${ }^{1, *}$, Zainal Arifin bin Mustapha1 \\ ${ }^{1}$ Faculty of Medicine \& Health Sciences, Universiti Malaysia Sabah, Malaysia \\ ${ }^{2}$ Faculty of Medicine, Bioscience \& Nursing, MAHSA University, Malaysia
}

Received July 10, 2019; Revised January 10, 2020; Accepted February 25, 2020

Copyright $\bigcirc 2020$ by authors, all rights reserved. Authors agree that this article remains permanently open access under the terms of the Creative Commons Attribution License 4.0 International License

\begin{abstract}
Introduction: There is a number of research elaborating the role played by the emotional intelligence in educational performance at primary and high school level but seldom among medical students. Objective: The aim of this review paper is to ascertain the relationship between emotional intelligence and academic performance among the medical students. Materials and methods: All articles searched using relevant finalised MeSh (Medical Subject Headings: is the NLM controlled vocabulary thesaurus used for indexing articles for PubMed.) terms are of English language between the years 1980 and 2018 among the following electronic database Ovid - MedLine, ProQuest, Scopus, Science Direct, CINAHL. Articles are further filtered based on the inclusion and exclusion criteria set up by the reviewers with mutual consent. Knowledge about academic output based on the methods involved in measuring emotional intelligence and study design was extracted. Results: The literature review cited 511 relevant articles. These articles are further scrutinised by removing duplicates, considering full text articles, and abstract review availed 07 articles which were considered for final review. It was found that six out of seven showed women had higher EI than men and only one of the seven showed no difference between men and women. Conclusion: In line with literature review, one can safely conclude emotional intelligence (EI), in general, improves academic performance. However, in contrast it is also seen among medical students the EI decreasing over the time of study years. Further research is necessary to find out the cause for this decline in emotional intelligence during the course and whether timely intervention of structured training can improve or not.
\end{abstract}

Keywords Emotional Intelligence, Academic Performance, Medical Students

\section{Introduction}

Educational training and success go beyond the IQ levels as from time immemorial; thrust on IQ alone was very significant across the population in the World. It was believed that abstract intelligence alone was good enough for problem solving, but frequent failures, underperformance and inability to handle social issues among the students lead researchers to come out with different approaches to confirm the associated factors that are needed in addition to IQ for academic achievement and deriving a conclusion that only intelligent mind is not enough to cope and upgrade once academics but rather emotional mind set to obtain successful achievements[1]. Basic knowledge of literature regarding emotional intelligence (EI) concept has been around for more than a century[2]. Many research studies across the world provided enough information/data to formulate the concept of emotional intelligence[3] and over the years it has been fine-tuned demonstrating a slightly higher accent and is trainable over Intelligence Quotient (IQ) as articulated by Goleman in the year 1995. Emotional intelligence was defined as "the ability to monitor one's own and other people's emotions, to discriminate between different emotions and label them appropriately, and to use emotional information to guide thinking and behavior"[3].

Most of the associated factors for emotional intelligence are inborn talents which were once identified and recognised, and can be trained professionally or through experiences in life for success[4]. Few studies revealed that EI is a better accessor of success when compared with traditionally thought intelligent quotient (IQ) [5] , Further research studies have described that emotional intelligence can be better understood and described in four components: (1) recognition of emotions in self (2) recognition of emotions in others (3) regulation of emotions in self (4) 
regulation of emotions in others[6, 7].

Considering its popularity among research community wide across, many research studies have emerged in recent years and have postulated many definitions, models and theories.

Many models of emotional intelligence are available, but only three are popular among the research scholars around the world [8-10].

(1) Mayer and Salovey's ability model of emotional intelligence[3, 8].

(2) Goleman's competencies model of emotional intelligence[5, 9].

(3) Bar-on's model of emotional intelligence[10].

Further research studies have prompted categorizing the emotional intelligence models into two types: (1)ability models and (2)trait and mixed models [3, 9, 11, 12].

Studies have revealed that persons with higher emotional intelligence are more balanced and better prepared to handle various social life challenges pertaining to self or neighbours[13].

Further research findings highlighted that there is a positive correlation between emotional intelligence and academic performance [14-16]. Based on the research evidence, support of emotional intelligence is one of the predictors of academic performance[17]. It is also seen that improved inter and intra personal emotional intelligence that leads to behavioural changes improves academic performance[18].

Similarly, few studies have shown that students with low emotional intelligence and anxiety displayed low attitude towards academics[19, 20].

Further studies ascertain that emotional intelligence skills may be modified and improved by structured training[21, 22]. This implies to improve academic performance of the students in the educational set up, designing of an appropriate training module that recognises the students' emotional level and caters to train them accordingly.

Several evidence depicts that in clinical setup training, individuals are appropriately trained in handling emotional intelligence, displaying more empathy in medical consultation, improving doctor - patient conversation and thereby better clinical outputs[23, 24]. This leads to possible conclusion that emotional intelligence plays a vital role in producing balanced, composed and competent doctor.

However, the available data worldwide about effect of emotional intelligence on academic performance among medical students is very scanty. This may be due to: it's a new concept slowly gaining importance among research scholars in medical fraternity, lack of universal agreement upon single tool to measure emotional intelligence considering its strength and weakness. Hence there is a need to establish the available data in a systematic and scientific way to understand the extent to which emotional intelligence and academic performance have been studied world-wide and we proposed a systematic review to confirm the same.

\section{Materials and Methods}

\subsection{Search Strategy}

An extensively comprehensive research was done. All articles searched using relevant and finalized MeSH terms of English language between the years 1980 and 2018 among the following electronic database Ovid, MedLine, ProQuest, Scopus, Science Direct, CINAHL until December 2018 with the following algorithm using " AND" , "OR" Boolean charters: "emotional intelligence" AND "EI" AND “emotional quotient" AND "EQ" AND "academic performance" OR "academic achievement" OR "academic success" OR "educational achievement" OR "educational assessment" OR Educational measurement. Thus article references were obtained and scrutinized for duplicates and further filtered incorporating inclusion and exclusion criteria to article references with medical students only by two researchers independently, any disputes arising were discussed and settled with mutual agreement with referral to a third researcher based on inclusion and exclusion criteria related to article's on medical school only ( specifically to emotional intelligence and academic performance)

\subsection{Study Selection}

All published research articles which are related to association between emotional intelligence and academic performance were considered and reviewed.

\subsection{Inclusion Criteria}

1. Research studies which depict association between emotional intelligence and academic performance among medical students are with correlation.

2. Using at least one of EI measurement and grades as a measure of academic performance.

3. Articles published in English language between the years 1980 to 2018 ie, are up to end of December 2018.

\subsection{Exclusion Criteria}

\section{A. Initial exclusion - Primary}

1. Non-English articles.

2. Articles that could not be accessed(unpublished/in press )

3. Study done in school children.

4. Studies done in others than medical students groups (allied health, dental, nursing etc) 
5. Post graduate studies, Diploma and spiritual studies.

\section{B. Exclusion after reading full text- Secondary}

1. Duplicate articles.

2. Not presenting original data, longitudinal studies

3. Correspondence or technical briefs, reviews

4. Correct effect measure not provided. (for EI or academic performance)

5. Solo gender research data (only males, only females or no clarity on gender).

\subsection{Data Extraction}

Extraction and assessment is done primarily by two researchers with the following pre agreed standardized check list which enquired about: Year of publication, sample size, author's name, age groups, gender, study design, study setting, number of male \& female participants ,emotional intelligence measuring tools , academic performance grading. The researchers then complied and tabulated the study Data obtained for further comparative analysis (ie, EI vs AP).

\section{Results}

Initial round of collective research analysis using $\mathrm{MeSH}$ key words along with inclusion and primary exclusion criteria in database revealed about 511 articles (Table 1), further scrutinising of these articles with removing duplicates, articles without relevant title abstract only articles which amounts to exclude about $(n=209)$ articles. Further complied in ENDNOTE reveals about $(n=302)$ articles. After the Exclusion of ( $\mathrm{n}=295)$ applying secondary exclusion criteria of the remaining fully accessible articles reveals about $(n=07)$ which were considered for final review (Figure 1).

Table 1. Comprehensive database-analysis

\begin{tabular}{|c|c|c|}
\hline Sl.No & DATABASE & $\begin{array}{c}\text { RETALED ARTICLES } \\
\text { FOUND }\end{array}$ \\
\hline 1 & EBSCohost(CINAHL) & 276 \\
\hline 2 & OVID -MEDLINE & 47 \\
\hline 3 & PROQUEST & 174 \\
\hline 4 & Scopus & 14 \\
\hline 5 & Total & 511 \\
\hline
\end{tabular}

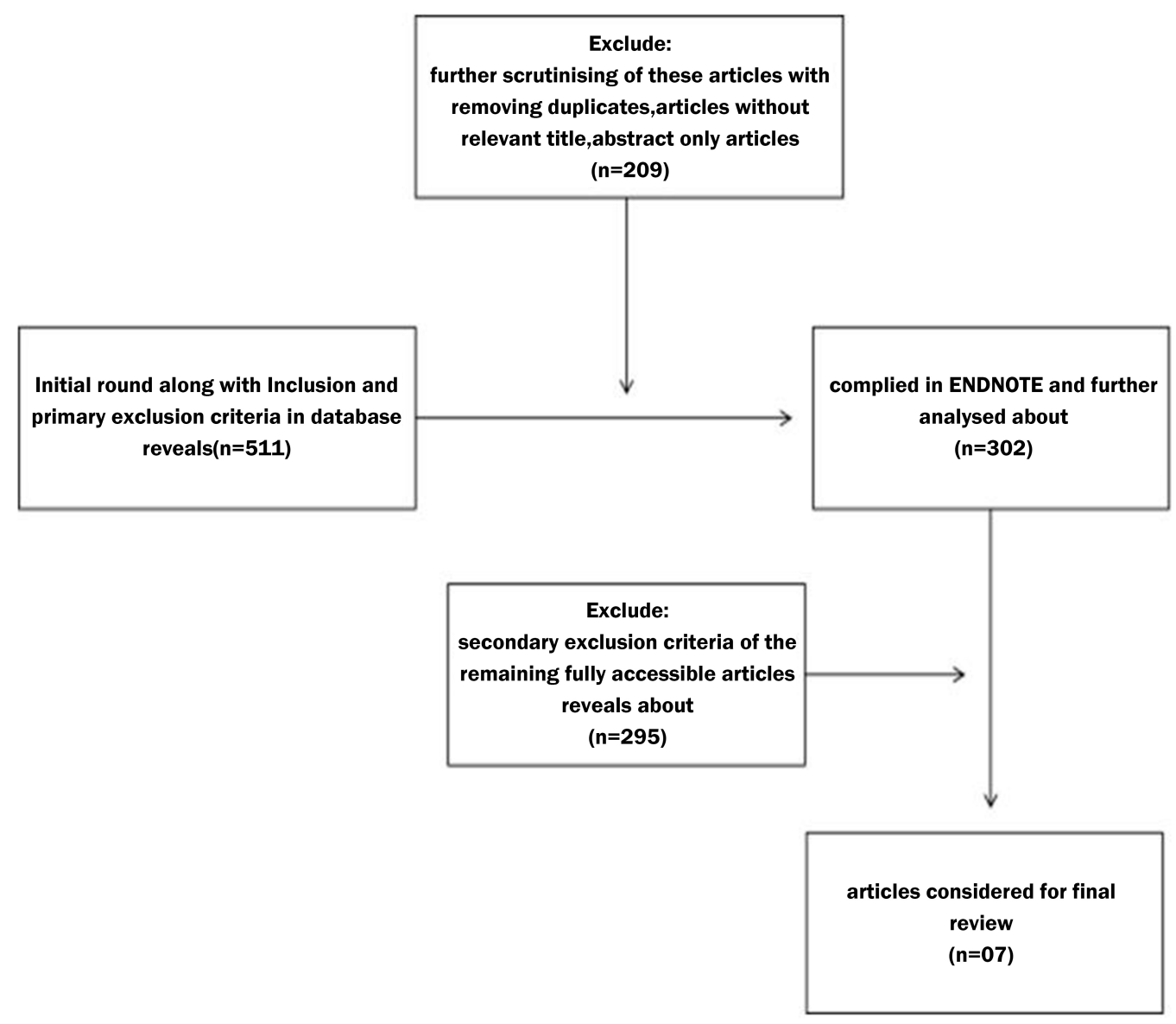

Figure 1. Process of study selection for analysis 


\section{Discussion}

With the age-old traditional belief of intelligence quotient(IQ) as one of the only measures that was upheld over years as a sole contributor for academic performance and excellence, educational domains were focusing solely on IQ. As many a time academic was restricted within the four walls of class rooms to practical halls, there were not enough avenues to test the role of EI in education or its possible role in the academic performance. This review solely focused on relationship of emotional intelligence on academic performance among undergraduate medical students in cross sectional studies. Emotional intelligence is found to be affected by many variables as depicted by various studies in line with this present study review aiming at such variables including gender, age, years of study etc.

Authors with consent complied and summarised all 7 papers and numbered (sl.no: 1,2..7,Table2) them to streamline analysis. Out of the 7 studies reviewed, the total sample size analysed in total is around $1858(100 \%)$ out of 873 males (47\%) and 985 females (53\%). Female population was found to be slightly $(6 \%)$ higher than males.

Among the six out of seven studies which have been reviewed extensively ${ }^{[25,27,28,29,30,31]}$, it reveals that females have higher emotional intelligence. Many earlier research studies have pointed out that gender plays a vital role in balancing emotional intelligence and females who most of the time were able to maintain higher emotional intelligence when compared to males ${ }^{[32,33]}$. Or the other reason probably could be due to the fact that female population was slightly more in number compared to males among the study groups. On contrast, one out of seven studies reviewed showed that there is no significant correlation between genders as in line with other studies ${ }^{[26]}$

Only three of the seven studies reviewed have accessible mean age of the study samples size recruited (table 2). Among the three available data one research cohort (sl.no:7, mean $=18.6$ ) is below 20 years of age while other two (sl.no: $5 \& 4$ mean $=21.8 \& 26.3$ ) are above 20 years of age. Even though the age groups are different among the study cohorts, results are similar and no difference in emotional intelligence or academic performance is observed as in line with other non-medical cohort studies. ${ }^{[34]}$ On contrary, several other studies in non-medical cohort suggest that emotional intelligence progresses as age advances ${ }^{[35]} \mathrm{In}$ general, six (sl.no:1,2,3,5,7 table 2) among the seven studies reviewed indicate positive correlation of emotional intelligence and academic performance. On the other hand, only one study among seven showed sparsely correlation (sl.no:6, table 2). Studies reveal that emotional intelligence has a major role to play in balancing learning process and to interpret emotions among medical students professional accent which may enhance their skills in patient care. Studies have shown that specialised tailored training can improve emotional intelligence unlike intelligence quotient. 
Table 2. Detail particulars of the studies involved

\begin{tabular}{|c|c|c|c|c|c|c|c|c|}
\hline \multicolumn{2}{|c|}{ Sl.No } & 7 & 6 & 5 & 4 & 3 & 2 & 1 \\
\hline \multicolumn{2}{|c|}{ (Source) Authors/year } & Austin et al (2005) & Austin et al (2007) & $\begin{array}{l}\text { BoonHow Chew et al } \\
\text { (2013) }\end{array}$ & $\begin{array}{l}\text { Naghma naeem et } \\
\text { al (2014) }\end{array}$ & $\begin{array}{l}\text { Chandrani nirmala } \\
\text { wijekoon et al } \\
\text { (2017) }\end{array}$ & $\begin{array}{l}\text { P.Ranasinghe et al } \\
\text { (2017) }\end{array}$ & $\begin{array}{l}\text { Ashwini Aithal P } \\
\text { et al (2017) }\end{array}$ \\
\hline \multicolumn{2}{|c|}{ Sample size } & $\begin{array}{l}156 \text { ( } 2 \text { students not } \\
\text { given gender) }\end{array}$ & 273 & 163 & 467 & 130 & 471 & 200 \\
\hline \multicolumn{2}{|c|}{ boys } & 51 & 85 & 51 & 334 & 50 & 209 & 93 \\
\hline \multicolumn{2}{|c|}{ girls } & 103 & 188 & 112 & 133 & 80 & 262 & 107 \\
\hline \multicolumn{2}{|c|}{ Sample frame } & $\begin{array}{l}\text { First year Medical } \\
\text { students (UK) }\end{array}$ & $\begin{array}{l}\text { year 2,3(pre-clinical) } \\
\text { \&year 5(clinical) (UK) }\end{array}$ & $\begin{array}{l}\text { first year \& final year } \\
\text { medical students } \\
\text { (Malaysia) }\end{array}$ & $\begin{array}{l}\text { year1 to year } 5 \\
\text { sttudents (saudi } \\
\text { arabia) }\end{array}$ & $\begin{array}{l}\text { final year results in } \\
\text { first attempt } \\
\text { (Srilanka) }\end{array}$ & year $2,4 \& 5$ (Srilanka) & $\begin{array}{l}\text { year 1 MBBS } \\
\text { (India) }\end{array}$ \\
\hline \multicolumn{2}{|c|}{ Study design } & Cross sectional & Cross sectional & Cross sectional & Cross sectional & Cross sectional & Cross sectional & Cross sectional \\
\hline \multicolumn{2}{|c|}{ Mean age } & 18.6 & NA & 21.8 & NA & $26.3 \pm 1$ & NA & NA \\
\hline \multirow{2}{*}{$\begin{array}{c}\text { age } \\
\text { percentage } \\
\text { distribution }\end{array}$} & majority & $17-19(88 \%)$ & NA & NA & $17-22(71 \%)$ & NA & NA & NA \\
\hline & minor & $20-28(12 \%)$ & NA & NA & $23-28(29 \%)$ & NA & NA & NA \\
\hline \multicolumn{2}{|c|}{$\begin{array}{c}\text { EIMS } \\
\begin{array}{c}\text { (Emotional intelligence } \\
\text { measuring scale) }\end{array} \\
\end{array}$} & EI scale(41items) & $\begin{array}{l}\text { EI scale(41items) } \\
\text { modified }\end{array}$ & MSCEIT & $\begin{array}{l}\text { SSREI scale }(33 \\
\text { items) }\end{array}$ & $\begin{array}{l}\text { Genos EI ( } 17 \text { items } \\
\text { in } 7 \text { domains) }\end{array}$ & SEIT(33 Item) & $\begin{array}{l}\text { TEIQue-SF( } 30 \\
\text { Items) }\end{array}$ \\
\hline \multicolumn{2}{|c|}{$\begin{array}{c}\text { AP } \\
\text { (Academic performance) }\end{array}$} & term end exams & year end exam & $\begin{array}{l}\text { continuous assessment } \\
\text { (CA) \& final examination } \\
\text { (FE) }\end{array}$ & CGPA & final year exam & year end exam & $\begin{array}{l}\text { year } 1 \text { final exam } \\
\text { marks }\end{array}$ \\
\hline \multicolumn{2}{|c|}{ Summary (general ) } & $\begin{array}{l}\text { 1) EI correlates with } \\
\text { exam performance on } \\
\text { health and society } \\
\text { module } \\
\text { 2) no association } \\
\text { between EI and exam } \\
\text { performance in } \\
\text { biomedical science }\end{array}$ & $\begin{array}{l}\text { no significant association } \\
\text { between EI and end of } \\
\text { year exam marks, for any } \\
\text { of the year groups }\end{array}$ & $\begin{array}{l}\text { 1) EI was a significant of } \\
\text { academic performance in } \\
\text { overall continuous } \\
\text { assessments and final } \\
\text { examination among } \\
\text { year } 1 \& \text { final year } \\
\text { 2) Year } 5 \text { better handle EI } \\
\text { compared to year } 1\end{array}$ & $\begin{array}{l}\text { A significant } \\
\text { positive correlaton } \\
\text { was found } \\
\text { between CGPA } \\
\text { and EI }\end{array}$ & $\begin{array}{l}\text { one way anova } \\
\text { revealed total EI } \\
\text { score was higher } \\
\text { among those with } \\
\text { better academic } \\
\text { performance }\end{array}$ & $\begin{array}{l}\text { 1) Higher EI was } \\
\text { associated with academic } \\
\text { performance among final } \\
\text { year students. } \\
\text { 2) final year students had } \\
\text { higher EI score } \\
\text { (p<0.001), those who } \\
\text { passed clinical science } \\
\text { examination in first } \\
\text { attempt }\end{array}$ & $\begin{array}{l}\text { majority of the } \\
\text { students with } \\
\text { higher EI scores } \\
\text { had higher } \\
\text { academic } \\
\text { performance } \\
\text { (r=0,51) with } \\
\text { linear relationship }\end{array}$ \\
\hline \multicolumn{2}{|c|}{ beginning of year } & $\begin{array}{l}\text { EI significantly } \\
\text { associated with health } \\
\text { and society exam ,first } \\
\text { exam taken at the end } \\
\text { of autum } \\
\text { (r }[154]=0.22, \mathrm{p}=0.007)\end{array}$ & NA & NA & NA & NA & \multirow{2}{*}{$\begin{array}{l}\text { EI scores from year } 1 \text { to } \\
\text { year } 5 \text { were similar and } \\
\text { did not show any } \\
\text { improvement or decrease }\end{array}$} & NA \\
\hline \multicolumn{2}{|c|}{ later in year } & $\begin{array}{l}\text { EI not significantly } \\
\text { correlated with health } \\
\text { and society later in the } \\
\text { year }\end{array}$ & NA & NA & NA & NA & & NA \\
\hline
\end{tabular}


Table 2 (Continued)

\begin{tabular}{|c|c|c|c|c|c|c|c|}
\hline Summary (specific ) & $\begin{array}{l}\text { 1) females were found } \\
\text { to score significantly } \\
\text { higher than males on } \\
\text { the first two health and } \\
\text { society exam } \\
\text { 2) no gender difference } \\
\text { in scores on } \\
\text { biomedical science } \\
\text { exams }\end{array}$ & $\begin{array}{l}\text { no significant gender } \\
\text { differences in the end of } \\
\text { year exam marks in all } \\
\text { the year groups }\end{array}$ & females performed better & $\begin{array}{l}\text { females scored } \\
\text { slightly higher on } \\
\text { emotion sub } \\
\text { scale, but over all } \\
\text { EI was } \\
\text { comparable for the } \\
\text { two genders }\end{array}$ & $\begin{array}{l}\text { 1) females in } \\
\text { comparsion to males } \\
\text { performed better } \\
\text { 2) both EI and } \\
\text { academic scores } \\
\text { were higher among } \\
\text { females }\end{array}$ & $\begin{array}{l}\text { Females had higher EI } \\
\text { scores }(p=0.014)\end{array}$ & $\begin{array}{l}\text { females EI scores } \\
\text { was higher }(72.27 \\
\pm 8.84) \text { than males } \\
(67.47 \pm 15.43) \\
(\mathrm{p}=007)\end{array}$ \\
\hline
\end{tabular}

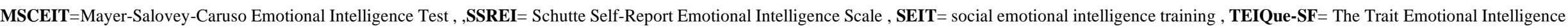
Questionnaire- Short form 
One of the studies (sl.no:7) reveals that emotional intelligence and academic performance decrease from first year to final year as in line with the other studies [36] Another study (sl.no:2) reveals no significant association seen between emotional intelligence among students studying in different years of medical programme suggesting emotional intelligence remains same during the five years of medical programme study period.

In general, the findings of this current review give a comparison and contrast relationship between emotional intelligence and academic performance among the medical students underlining the need of more data in this regard.

\section{Conclusions}

In conclusion, this literature review concludes that higher emotional intelligence may improve academic performance in the medical students. Its incorporation into medical curriculum may help students to identify their emotional traits and it gives opportunity to train them to a better level and to handle emotional intelligence, thereby improving academic performance. However, in contrast, it is also seen among medical students that emotional intelligence is decreasing over the time of study years gradually. Further research is necessary to find out the cause for this decline in emotional intelligence during the course of study and whether timely intervention of structured training can improve to sustain emotional intelligence and contribute in their academic performance. Such comprehensive correlated information may guide medical school's who are constantly looking for ways to produce doctors with higher emotionally intelligent thereby perform better in their examination in acquiring right knowledge and skill to deliver good patient care and communication with productive teamwork.

\section{Limitations}

Our study among the final 07 peer-reviewed articles looked into only those research studies which focused on medical schools, faced difficulties in drawing uniform conclusion as each research studies used different EI measuring tools and very few had indicated response rate.

\section{Acknowledgements}

We acknowledge UMS in providing access to library facilities for sourcing resource materials. (GRANT: UMSGreat-GUG0251-1/2018)

\section{REFERENCES}

[1] Low GR, Nelson D. Emotional intelligence: The role of transformative learning in academic excellence. Texas Stud Second Edu 2005;14(2):41-4.

[2] Dahl H. Frames of mind. Psychoanalytic process research strategies: Springer; 1988. p. 51-66.

[3] Salovey P, Mayer JD. Emotional intelligence. Imagination, cognition and personality 1990;9(3):185-211.

[4] Boyatzis RE, Goleman D, Rhee K. Clustering competence in emotional intelligence: Insights from the Emotional Competence Inventory (ECI). Handbook of emotional intelligence 2000;99(6):343-62.

[5] Goleman D. An EI-based theory of performance. The emotionally intelligent workplace: How to select for, measure, and improve emotional intelligence in individuals, groups, and organizations 2001;1:27-44.

[6] Davies M, Stankov L, Roberts RD. Emotional intelligence: In search of an elusive construct. J Personal Soc Psychol 1998;75(4):989.

[7] Law KS, Wong C-S, Song LJ. The construct and criterion validity of emotional intelligence and its potential utility for management studies. J Appl Psychol 2004;89(3):483.

[8] Salovey PE, Sluyter DJ. Emotional development and emotional intelligence: Educational implications: Basic Books; 1997.

[9] Goleman D, Welch S, Welch J. What Makes a Leader?: Findaway World, LLC New York; 2012.

[10] Bar-On R. The Bar-On model of emotional-social intelligence (ESI). Psicothema 2006;18:13-25.

[11] Bar-On R. The Emotional Quotient Inventory (EQ-i): A test of emotional intelligence. Multi-Health Systems. Inc, Toronto 1997.

[12] Petrides KV, Pita R, Kokkinaki F. The location of trait emotional intelligence in personality factor space. Brit $\mathbf{J}$ Psychol 2007;98(2):273-89.

[13] Brackett MA, Salovey P. Measuring emotional intelligence with the Mayer-Salovery-Caruso Emotional Intelligence Test (MSCEIT). Psicothema 2006;18:34-41.

[14] Fahim M, Pishghadam R. On the role of emotional, psychometric, and verbal intelligences in the academic achievement of university students majoring in English language. Iranian EFL J 2007;4.

[15] Petrides KV, Frederickson N, Furnham A. The role of trait emotional intelligence in academic performance and deviant behavior at school. Personal Ind Diff 2004;36(2):277-93.

[16] Elias M, Zins J, Weissberg R. Promoting social and emotional learning: Guidelines for educators. Adolescence 2000;35(137):221.

[17] Codier E, Odell E. Measured emotional intelligence ability and grade point average in nursing students. Nurse Edu Today 2014;34(4):608-12.

[18] Brackett MA, Rivers SE, Salovey P. Emotional intelligence: Implications for personal, social, academic, and workplace success. Soc Personal Psychol Comp 2011;5(1):88-103.

[19] CHOW BWY, Chiu MM, Wong SWL. Emotional 
Intelligence, Social Problem-Solving Skills, and Psychological Distress: A Study of Chinese Undergraduate Students 1. J Appl Soc Psychol 2011;41(8):1958-80.

[20] Hen M, Goroshit M. Academic self-efficacy, emotional intelligence, GPA and academic procrastination in higher education. Eur J Soc Sci 2014;2(1):1-10.

[21] Goleman D. Emotional intelligence. Why it can matter more than IQ. Learning 1996;24(6):49-50.

[22] Dulewicz V, Higgs M. Can emotional intelligence be developed? Int J Hum Res Manag 2004;15(1):95-111.

[23] Hojat M, Mangione S, Nasca TJ, Rattner S, Erdmann JB, Gonnella JS, et al. An empirical study of decline in empathy in medical school. Med Edu 2004;38(9):934-41.

[24] Woloschuk W, Harasym PH, Temple W. Attitude change during medical school: a cohort study. Med Edu 2004;38(5):522-34.

[25] Aithal AP, Kumar N, Gunasegeran P, Sundaram SM, Rong LZ, Prabhu SP. A survey-based study of emotional intelligence as it relates to gender and academic performance of medical students. Edu Health 2016;29(3):255.

[26] Ranasinghe P, Wathurapatha W, Mathangasinghe Y, Ponnamperuma G. Emotional intelligence, perceived stress and academic performance of Sri Lankan medical undergraduates. BMC Med Edu 2017;17(1):41.

[27] Wijekoon CN, Amaratunge H, de Silva Y, Senanayake S, Jayawardane P, Senarath U. Emotional intelligence and academic performance of medical undergraduates: a cross-sectional study in a selected university in Sri Lanka. BMC Med Edu 2017;17(1):176.

[28] Chew BH, Zain AM, Hassan F. Emotional intelligence and academic performance in first and final year medical students: a cross-sectional study. BMC Med Edu 2013;13(1):44.

[29] Austin EJ, Evans P, Magnus B, O'Hanlon K. A preliminary study of empathy, emotional intelligence and examination performance in MBChB students. Med Edu 2007;41(7):684-9.

[30] Austin EJ, Evans P, Goldwater R, Potter V. A preliminary study of emotional intelligence, empathy and exam performance in first year medical students. Personal Ind Diff 2005;39(8):1395-405.

[31] Van Rooy DL, Alonso A, Viswesvaran C. Group differences in emotional intelligence scores: Theoretical and practical implications. Personal Ind Diff 2005;38(3):689-700.

[32] Arora S, Ashrafian H, Davis R, Athanasiou T, Darzi A, Sevdalis N. Emotional intelligence in medicine: a systematic review through the context of the ACGME competencies. Med Edu 2010;44(8):749-64.

[33] Wagner PJ, Mosley GC, Grant MM, Gore JR, Owens CL. Physicians' emotional intelligence and patient satisfaction. 2002.

[34] Weng H-C. Does the physician's emotional intelligence matter?: Impacts of the physician's emotional intelligence on the trust, patient-physician relationship, and satisfaction. Health Care Manag Rev 2008;33(4):280-8.
[35] Stratton TD, Saunders JA, Elam CL. Changes in medical students' emotional intelligence: An exploratory study. Teach Learn Med 2008;20(3):279-84. 